\title{
Diagnostic Evaluation of Developmental Delay/Mental Retardation: An Overview
}

\author{
AGATINO BATTAGLIA* AND JOHN C. CAREY
}

\begin{abstract}
Mental retardation (MR) is one of the few clinically important disorders for which the etiopathogenesis is still poorly understood. It is a condition of great concern for public health and society. MR is currently defined as a significant impairment of cognitive and adaptive functions, with onset before age 18 years. It may become evident during infancy or early childhood as developmental delay (DD), but it is best diagnosed during the school years. MR is estimated to occur in $1-10 \%$ of the population, and research on its etiology has always been a challenge in medicine. The etiopathogenesis encompasses so many different entities that the attending physician can sometimes feel a "virtual panic," starting a wide-range diagnostic evaluation. The Consensus Conference of the American College of Medical Genetics has recently established guidelines regarding the evaluation of patients with MR [Curry et al., 1997], emphasizing the high diagnostic utility of cytogenetic studies and neuroimaging in certain clinical settings. However, since then there has been substantial progress in molecular cytogenetics and neuroimaging techniques, the use of which has allowed recognition and definition of new disorders, thus increasing the diagnostic yield. This review will focus on the most appropriate investigations shown to be, at present, necessary to define the etiology of DD/MR, in the context of recommendations for the clinical evaluation of the patient with undiagnosed MR. (c) 2003 Wiley-Liss, Inc.
\end{abstract}

KEY WORDS: developmental delay; mental retardation; diagnostic evaluation

\section{INTRODUCTION}

Mental retardation (MR) represents an important chapter in medicine. It is one of the few clinically important disorders for which the etiopathogenesis is still poorly understood. It is a condition of great concern for public health and society. Public health sees it as a rather common abnormality, distributed amongst the entire population, with heavy and lifelong costs. Society sees it as a heavy burden with negative effects on productivity, associated with different degrees of limitations in self-direction and self-care, with consequent need for supervision, support, and protection. For the affected individual and his family, it represents a limitation, of variable degree, in all fields of daily living.

$M R$ is currently defined as a significant impairment of cognitive and adaptive functions, with onset before age 18 years. According to the intelligence quotient (IQ) (obtained by assessment with one or more of the standardized,
Dr. Agatino Battaglia is adjunct professor of pediatric neurology at the University of Pisa, Division of Pediatric Neurology and Psychiatry, Department of Procreative Medicine and Pediatrics; and adjunct professor of pediatrics at the University of Utah Health Sciences Center, Division of Medical Genetics, Department of Pediatrics. He is board certified in clinical pediatrics and in neurology. He is director of the Clinical Neurophysiology Service, head of the Center for the Study of Congenital Malformation Syndromes, and director of Research in Neuropsychiatric Genetics at the Stella Maris Clinical Research Institute for Child and Adolescent Neuropsychiatry, Calambrone (Pisa), Italy. He has a strong research interest in clinical neurophysiology, clinical dysmorphology, and neuropsychiatric genetics. He currently holds a grant of the Italian Ministry of Health devoted to studying the genetics and neurobiology of autism.

Dr. John C. Carey is a clinical geneticist, professor of pediatrics at the University of Utah Health Sciences Center, Division of Medical Genetics, Department of Pediatrics, Salt Lake City, Utah. He is the editor in chief of the American Journal of Medical Genetics.

Grant sponsor: International Program for Consultation and Research in Clinical Genetics of the University of Utah.

*Correspondence to: Dr. Agatino Battaglia, Stella Maris Clinical Research Institute for Child and Adolescent Neurology and Psychiatry, via dei Giacinti, 2, 56018 Calambrone (Pisa), Italy. E-mail: abattaglia@inpe.unipi.it

DOI 10.1002/ajmg.c.10015 individually administered tests), $\mathrm{MR}$ is subgrouped in four degrees of severity: mild MR, IQ level of 50-55 to approximately 70; moderate MR, IQ level of 35-40 to 50-55; severe MR, IQ level of 20-25 to 35-40; and profound MR, IQ level of below 20-25. Usually the presenting symptoms in individuals with MR are impairments in adaptive functioning. Adaptive functioning refers to how effectively individuals cope with everyday life demands, and how well they meet the standards of personal independence expected of someone of that particular age and socioeconomic and cultural background. Adaptive functioning may be influenced by various factors such as motivation, personality style, education, social and vocational opportunities, and the general medical conditions and mental disorders that may coexist with MR. Adaptive functioning is measured by standardized scales that allow the gathering of evidence for deficits from more than one reliable source [Sparrow et al., 1984; Achenbach, 1991]. As in the assessment of cognitive functioning, consideration should be given to the suitability of the instruments to the subject's ethnic 
and cultural background, education, motivation, cooperation, and associated handicaps.

MR may become evident during infancy or early childhood as developmental delay (DD), but it is best diagnosed during the school years. It is estimated to occur in $1-10 \%$ of the population [McLaren and Bryson, 1987; Drillien et al., 1988; Simeonsson and Sharp, 1992; Massey and McDermott, 1995; Stevenson, 1996]; the different rates of prevalence depend on definitions used, methods of ascertainment, and population studied. MR is seen more often in males (sex ratio of 1.5:1) [Penrose, 1938; Lehrke, 1968; American Psychiatric Association, 1995]. Possible explanations may be the biological inequity between males and females conferred by the different number of sex chromosomes, and by now well-established X-linked single-gene mutations.

Research on the etiology of MR has always been a challenge in medicine. There are many reasons to study the etiology of MR:

1. Diagnosis provides prediction.

2. It is often definitely sought by the family.

3. Only recognition of the causes may help in establishing an accurate recurrence risk; predicting the prognosis with relative certainty; organizing appropriate laboratory testing; avoiding diagnostic evaluation of unnecessary complexity, expense, and invasiveness; establishing a health maintenance plan; starting adequate treatment, when feasible; and referring the patient and the family to a support group.

In our experience, the communication of diagnosis has been crucial, in many instances, for the therapeutic alliance. In addition, an accurate diagnosis is the first step toward the study of behavioral phenotypes.

Being a disorder of brain formation and function, MR may result from genetic influences, environmental insults, or a combination of the two [Moser and Wolf, 1971; Opitz et al.,
1978; McLaren and Bryson, 1987]. The high frequency of the involvement of genes in the etiology of MR is reflected by the finding in Online Mendelian Inheritance in Man (OMIM) of 1,027 entries upon a search for "mental retardation." The etiopathogenesis encompasses so many different entities that the attending physician can sometimes feel a "virtual panic," starting a wide-range diagnostic evaluation. This feeling is magnified by the low diagnostic yield usually reported in the assessment of such patients [Moser and Wolf, 1971; Gustavson et al., 1977a,b; Laxova et al., 1977; Opitz et al., 1978; Moser et al., 1990]. However, these works mostly included patients with severe to profound MR; moreover, significant advances in laboratory testings over the last two decades have led to a substantial improvement in the diagnostic yield. The Consensus Conference of the American College of Medical Genetics has recently established guidelines regarding the evaluation of patients with MR [Curry et al., 1997]. These investigators emphasized the high diagnostic utility of cytogenetic studies and neuroimaging in certain clinical settings. A more recent study [Battaglia et al., 1999] on the diagnostic yield of the comprehensive assessment of DD/ MR, while confirming the diagnostic utility of cytogenetic/molecular genetic and neuroimaging studies, suggested the usefulness of accurate electroencephalogram (EEG) recordings and stressed the importance of a thorough physical examination. Most of these points were also supported by Hunter [2000] in his review of hospital and genetics clinic records of 411 patients evaluated for MR. Contrary to the most often expressed opinion that the diagnostic yield is greater in individuals with more severe MR [Bodensteiner and Schaefer, 1995], it is now obvious to us that the likelihood of making a diagnosis is independent of the category and degree of DD/MR [Battaglia et al., 1999; Hunter, 2000]. This may in part reflect both an improved ability in studying and diagnosing more subtle patterns of malformation (e.g., mild Wolf-Hirschhorn, mild Brachmannde-
Lange) and the availability of newer diagnostic techniques (e.g., fluorescence in situ hybridization (FISH), subtelomeric screening, comparative genomic hybridization, chromosome microdissection, interferometer spectral imaging or karyotyping (SKY), primed in situ labeling (PRINS), in vivo proton magnetic resonance spectroscopy (MRS) of the brain). Indeed, recent years have produced many exciting advances in dysmorphology, cytogenetics and molecular genetics, neuroimaging, and clinical neurophysiology that allow (or contribute to) the identification of the underlying cause of many previously undiagnosable cases of DD/MR.

Recent years have produced many exciting advances in dysmorphology, cytogenetics and molecular genetics, neuroimaging, and clinical neurophysiology that allow (or contribute to) the identification of the underlying cause of many previously undiagnosable cases of $D D / M R$.

This review will focus on the most appropriate investigations shown to be, at present, necessary to define the etiology of DD/MR, in the context of recommendations for the clinical evaluation of the patient with undiagnosed MR.

\section{HISTORY/PHYSICAL EXAMINATION}

An accurate prenatal/birth history and hereditary/familial history, together with a three-generation pedigree, should be an essential step in the evaluation of the patient with DD/MR [Curry et al., 1997].

The importance of a thorough physical examination (including a meticulous 
search for skin changes and a neuromotor assessment, with the documentation of minor anomalies and/or abnormal findings by detailed description and measurements) emerges from several reports in the literature [Curry et al., 1997; Root and Carey, 1997; Battaglia et al., 1999; Hunter, 2000; Nanni et al., 2001]. It is common experience that it can help either in making a diagnosis or in directing laboratory testing. Photographs and videos should be complementary tools, videotaping being invaluable in documenting posture, gait, any movement disorders, and behavior characteristics.

\section{As emerges from literature}

reports, it seems that the best use of subtelomeric analysis is in patients with moderate to severe MR associated with physical anomalies.

As already suggested by the Consensus Conference of the American College of Medical Genetics [Curry et al., 1997], serial evaluations of the patient, at times over several years, are often very useful for diagnosis. Both clinical and behavior phenotypes tend to modify over time in many congenital patterns of human malformation, allowing for the eventual recognition of many conditions. Moreover, systematic follow-up is also useful for a stepwise and cost-effective approach to diagnostic testing. The frequency of evaluations should vary in relation to the age of the patient, the severity and complexity of the clinical picture, and the urgency of reproductive concerns.

\section{CYTOGENETICS/ MOLECULAR CYTOGENETICS}

Contribution of chromosome aberrations to $\mathrm{DD} / \mathrm{MR}$ is generally said to be elevated. Chromosome abnormalities are reported in $4-34.1 \%$ of individuals with DD/MR [Bourgeois and
Benezech, 1977; Kodama, 1982; Opitz et al., 1982; Rasmussen et al., 1982; Wuu et al., 1984; Gustavson, 1977b Srsen et al., 1989; Wuu et al., 1991; Phelan et al., 1996; Felix et al., 1998; Hou et al., 1998; Battaglia et al.,1999; Hong et al., 1999; Cora et al., 2000], and cytogenetic analysis is regarded as a mainstay in the diagnostic process. However, guidelines regarding the type and resolution of the analysis to be performed and definite clinical indications for such studies are still debated. The Consensus Conference [Curry et al., 1997] endorsed the concept that any individual with DD/MR without a definite diagnosis requires a standard cytogenetic analysis at the 500band level. They also suggested that whenever there is a provisional diagnosis of microdeletion syndrome, a focused FISH analysis may be the first step; and in those patients whose phenotype may be shared between known nonchromosomal syndromes and chromosome aberrations (i.e., Brachmannde Lange syndrome and dup3q26-27), high- resolution chromosome analysis should be ordered.

However, the demonstration that both false negative and false positive results occur with high-resolution banding [Kuwano et al., 1992; Delach et al., 1994; Butler, 1995] led to the conclusion that this technique is insufficient for detection of deletions [ASHG/ACMG Report, 1996]. The availability, in few research centers, of new technical developments [Knight et al., 1997] has recently allowed molecular cytogenetic approaches in the study of unexplained MR. Since the discovery that subtelomere regions are gene rich [Saccone et al., 1992], with the possible consequence that rearrangements in these sites are likely to produce clinical patterns, subtelomeric analysis, employing different methods [Xu and Chen, 2003], has been performed in cohorts of individuals with undiagnosed MR.

As emerges from literature reports [Knight and Flint, 2000; Rossi et al., 2001; Biesecker, 2002], it seems that the best use of subtelomeric analysis is in patients with moderate to severe MR associated with physical anomalies.
In fact, submicroscopic subtelomeric chromosome defects have been found in $6.5-7.4 \%$ of children with moderate to severe MR [Knight and Flint, 2000; Rossi et al., 2001] vs. only 0.5\% [Knight et al., 1999] or even 10.3\% [Anderlid et al., 2002] of children with mild retardation. This latter discrepancy could be explained by the different size and selection of the study groups. Overall, due to the technical complexities, cost of screening, and the lack of testing facilities in every genetic center, an effective clinical preselection is recommended. For this purpose, de Vries et al. [2001] studied 29 patients with a known subtelomeric defect and assessed clinical variables such as family and birth history, facial dysmorphism, and congenital malformations. The data were compared with 110 control children with MR of unknown etiology, with normal standard cytogenetics and no detectable submicroscopic subtelomeric abnormalities. The authors concluded that good indicators for subtelomeric defects are 1) family history of MR, 2) prenatal onset growth retardation, 3) postnatal poor growth/overgrowth, 4) two or more facial dysmorphic features, and 5) one or more nonfacial dysmorphic features and/or congenital abnormalities.

\section{Good indicators for} subtelomeric defects are 1) family history of $M R$, 2) prenatal onset growth retardation, 3) postnatal poor growth/overgrowth, 4) two or more facial dysmorphic features, and 5) one or more nonfacial dysmorphic features and/or congenital abnormalities.

In spite of few criticisms [Baker et al., 2002; van Karnebeek et al., 2002], we believe that this five-item checklist 
might improve the diagnostic yield of subtelomeric analysis in the evaluation of DD/MR subjects, at least until more detailed clinical parameters and new and more efficient tests, such as genomic microarray [Xu and Chen, 2003], will be widely available.

\section{We believe that this five-item} checklist might improve the diagnostic yield of subtelomeric analysis in the evaluation of $\mathrm{DD} / \mathrm{MR}$ subjects, at least until more detailed clinical parameters and new and more efficient tests, such as genomic microarray, will be widely available.

Based on common clinical experience and literature reports, it seems relevant to underline that a growing number of DD/MR patients thought on first examination to be nonsyndromic turn out to be aneuploid or to have fragile X (FraX). In the study of Curry et al. [1996], 16/150 (11\%) children with undiagnosed DD had a chromosome abnormality. Four of these 16 children were described by the clinical geneticist as nondysmorphic. In the study carried out by Battaglia et al. [1999], 10.2\% of DD/MR children thought to be nonsyndromic turned out to be aneuploid, and 5.1\% had FraX. Lee et al. [2001] reported a 21/2-year-old Korean patient presenting with DD, speech delay, delay of gross motor milestones, and hypotonia, but no dysmorphic features, in whom cytogenetic and FISH studies showed a tandem $22 / 15$ translocation with deletion of the $22 \mathrm{q} 13.3$ region and retention of the NOR of chromosome 15. A few more patients with DD, absent or severely delayed speech, hypotonia, and only minor anomalies have been reported, in whom a deletion of the $22 q 13$ region was detected either on routine cytoge- netic analysis or on FISH/molecular analysis [Precht et al., 1998; Phelan et al., 2001]. As with many terminal deletions involving pale G-band regions, the deletion can be extremely subtle (cryptic terminal rearrangements) and can go undetected on routine cytogenetic analysis (even at the 850-band level) in almost $32 \%$ of the cases [Phelan et al., 2001].

Individuals with interstitial duplication of proximal $15 \mathrm{q}$ may present with DD/MR and autism spectrum disorder, but without consistent dysmorphic findings [Gurrieri et al., 1999; Mohandas et al., 1999]. Based on the presence of duplicated Prader-Willi/ Angelman syndrome critical region (PW/ASCR) loci and parent of origin of the duplication, the patients have been divided into three groups [Browne et al., 1997; Cook et al., 1997; Riordan and Dawson, 1998]. In the first group are patients with euchromatic variants of no clinical significance, without PW/ ASCR duplication. The second group includes patients with maternally inherited PW/ASCR duplications associated with DD/MR, autism/atypical autism, learning/speech difficulties, but with no consistent dysmorphic findings. The third group includes patients with paternally inherited PW/ASCR duplications with no apparent clinical phenotype [Riordan and Dawson, 1998]. However, a patient with DD, severe speech delay, and brain anomalies, whose duplication $15 q$ was of paternal origin and involved the PW/ASCR was reported by Mohandas et al. [1999]. The diagnosis in these patients may be missed on standard cytogenetic analysis or on FISH analysis as the sole investigation [Gurrieri et al., 1999; Thomas et al., 2002]. Complete cytogenetic and molecular characterization is recommended for the study of patients with suspected dup(15). It is, in fact, vitally important to detect these patients, since recurrence risk for these families could rise from the empiric risk of 3-7\% [Jorde et al., 1990; Piven et al., 1990; Szatmari et al., 1993; Bolton et al., 1994] up to $50 \%$ in the case of maternally carried duplication, with substantial implications for other family members.
Children with DD, moderate to severe MR, severe epilepsy with seizure onset between ages 4 and 8 years, diffuse hypotonia, and autistic behavior, with no dysmorphic findings or just one to four "minor anomalies," have been shown to have a maternally derived inv dup (15) involving the PW/ASCR [Flejter et al., 1996; Battaglia et al., 1997; Schroer et al., 1998]. There are two cytogenetic types of inv dup(15) [Maraschio et al., 1988]. One is a metacentric or submetacentric and heterochromatic chromosome, smaller or similar to a $G$ group chromosome, $\operatorname{dic}(15)$ (q11). Most children with this aberration have an apparently normal phenotype [Cheng et al., 1994]. The second type of inv dup(15) is as large as, or larger than, a $G$ group chromosome and has 15q euchromatin. It includes the PW/ASCR [Robinson et al., 1993; Blennow et al., 1995], and the cytogenetic description is $\operatorname{dic}(15)$ (q12 or $\mathrm{q} 13)$. This dicentric 15 is derived from the two homologous maternal chromosomes at meiosis and is usually associated with increased maternal age and with the abnormal phenotype reported above. In all such cases, standard cytogenetics must be associated with FISH analysis.

DD, usually of mild degree, and hypotonia, associated either with a normal phenotype or with a PraderWilli-like phenotype, have been described in patients with UPD14mat [Papenhausen et al., 1995; Berends et al., 1999; Hordijk et al., 1999; Martin et al., 1999]. UPD14pat has also been shown to be associated with MR and a normal phenotype [Papenhausen et al., 1995] or with MR and different types of anomalies [Walter et al., 1996; Cotter et al., 1997]. UPD14 seems therefore another possible cause of DD/MR and should be searched for at least in definite cases by means of DNA analysis. This could further improve the diagnostic yield and counseling in these families.

Mild to severe DD/MR, associated with hypotonia and variable signs of nonspecific developmental abnormalities, has been reported in individuals with either a de novo 16p deletion [Lindor et al., 1997] or a subtelomeric $16 \mathrm{p}$ deletion as a consequence of an 
inherited balanced cryptic subtelomeric translocation, $\mathrm{t}(3 ; 16)(\mathrm{q} 29 ; \mathrm{p} 13.3)$, segregating in the family [HolinskiFeder et al., 2000]. In the latter cases, the authors were able to uncover the etiology of DD/MR following a genome search (due to the large size of the family) and subsequent FISH analysis with subtelomeric $16 \mathrm{p}$ probes (extended cytogenetic analysis, including the use of high-resolution karyotyping, multiplex (M-) FISH, and DNA FraX, could not reveal the cause of DD/MR). Such cases once more point out the importance of subtelomeric chromosomal microrearrangements in idiopathic MR, not only in sporadic cases or in small families, but also in large pedigrees, irrespective of the suspected inheritance pattern.

Since the description of mutations in the methyl-CpG binding protein 2 (MECP2) gene in Rett syndrome (RTT; MIN 312750) [Amir et al., 1999; Bienvenue et al., 2000; Cheadle et al., 2000; De Bona et al., 2000; Huppke et al., 2000; Kim and Cook, 2000; Xiang et al., 2000], a few reports have shown that MECP2 mutations are not necessarily lethal in males. The male patients can show severe MR with progressive neurological symptoms [Meloni et al., 2000; Villard et al., 2000] or a nonfatal, nonprogressive encephalopathy [Imessaoudene et al., 2001] or an Angelman-like phenotype [Watson et al., 2001] or a moderate to severe nonspecific X-linked MR (MRX) [Orrico et al., 2000; Couvert et al., 2001]. Even more intriguing appears to be the possibility that males with mild nonspecific MR with no phenotypic anomalies can have an in-frame deletion in MECP2 [Yntema et al., 2002]. These authors screened the DNA of one affected male from 176 families, collected by the European XLMR consortium, in which MR occurred as a trait compatible with $\mathrm{X}$-linked inheritance. The screening was performed for mutations in the entire coding region of the MECP2 gene. A mutation was detected only in one family, which included three affected males in two generations. All affected males showed mild nonspecific MR without any physical or neurological anomalies. How $M E C P 2$ mutations lead to $\mathrm{MR}$ is unclear as of yet, but these reports disclose new horizons concerning the diagnostic evaluation of $\mathrm{DD} / \mathrm{MR}$, particularly bearing in mind that only few years ago, it was common belief that mild DD/MR could be due to cultural and familial rather than pathological causes.

Recent reports in the literature draw attention to a complex developmental disorder characterized by MR, delayed motor development, and distinct facial features (hypertelorism, abnormal eyebrows, low nasal root, prognathism), associated in some patients with microcephaly, epilepsy, Hirschsprung disease (HSCR) or just constipation, heart defects, hypospadias, and corpus callosum agenesis. In a minority of cases, a de novo translocation involving chromosome $2 \mathrm{q} 22$ or an interstitial deletion of chromosome $2 \mathrm{q} 22$ was detected on standard cytogenetics [Lurie et al., 1994; Mowat et al., 1998; Amiel et al., 2001; Wakamatsu et al., 2001], whereas in the remainder, a variety of different mutations in (ZFHX1B) SMADIP1, encoding Smad-interacting protein1 (SIP1), were detected on molecular analysis [Yamada et al., 2001; Zweier et al., 2002]. This syndrome appears to be less rare than originally expected, and we believe that SMADIP1 mutations should be part of the diagnostic evaluation of DD/MR patients presenting with distinct facial features, $+/-$ microcephaly, +/-HSCR/constipation, +/corpus callosum agenesis.

From recent literature reports, it looks like $1 \mathrm{p} 36.3$ deletions account for $0.5-0.7 \%$ of idiopathic MR [Giraudeau et al., 1997, 2001]. This emerging chromosomal disorder is associated with DD/MR, hypotonia, growth abnormalities, and distinct craniofacial dysmorphism (prominent forehead, deep-set eyes, flat nasal bridge, midface hypoplasia, pointed chin) [Slavotinek et al., 1999]. Cardiomyopathy, seizures, and enlarged ventricles occasionally associated with a squat corpus callosum or leukodystrophy can also occur [Battaglia et al., 2001b]. Although the deletion can be detected by high resolution banding (HRB), confirmation by FISH is required in most cases, and subtelomeric FISH analysis has been necessary in others [Giraudeau et al., 1997, 2001; Riegel et al., 1999; Battaglia et al., 2001b]. Based on the relative frequency of this chromosomal aberration in DD/ MR children with nonspecific anomalies, we would recommend that subtelomere analysis for $1 \mathrm{p} 36$ be routinely performed in patients with unclassified multiple congenital anomalies (MCA)/ MR syndromes or apparent idiopathic DD/MR.

Recently, Williams et al. [2001] drew attention to the Angelman syndrome (AS) mimicking conditions and phenotypes. These were grouped into the areas of chromosome, single-gene, and symptom complex anomalies. 22q13.3 terminal deletions seem to be the most mimicking of the AS among chromosome aberration. However, other chromosome anomalies, such as duplication of 15q11-13 (on rare cases), interstitial deletion of 2q21-23, 17q23.2, 4q, should be kept in mind when evaluating a patient with an AS clinical phenotype. Rett syndrome is probably the most common AS mimicker during the infant and toddler ages [Ellaway et al., 1998]. Methylene tetrahydropholate reductase deficiency (MTHFR) can present with DD/MR, absent speech, ataxia, seizures, and happy demeanor [Arn et al., 1998]. Profound MR and protruding tongue can be seen in ATR-X syndrome [Gibbons et al., 1995]. However, patients with nonspecific MR (even of mild degree), no positive family history, and no laboratory evidence for alphathalassemia have also been reported to have mutations of the ATR-X gene [Villard et al., 1999; Guerrini et al., 2000].

\section{METABOLIC WORKUP}

The importance of inborn errors of metabolism as a cause of DD/MR conditions is widely recognized. However, given their generally low prevalence in children with DD/MR $(0-5 \%)$ [Opitz et al., 1982; Wuu et al., 1991; Majnemer and Shevell, 1995; Allen and Taylor, 1996], the Consensus Conference 
[Curry et al., 1997] recommended that "metabolic testing be selective and targeted at the suspected category of disorder." Identical suggestions derived from following studies on $\mathrm{DD} / \mathrm{MR}$ patients [Battaglia et al., 1999; Hunter, 2000].

However, it's worth noting that patients presenting with nonregressive early-onset encephalopathy characterized by severe neonatal hypotonia, DD, and cerebellar signs, but with no dysmorphic features or only minor facial anomalies, have been reported to have CDG-1a [Drouin-Garraud et al., 2001]. Congenital disorder of glycosylation (CDG) is a group of metabolic disorders usually presenting with severe neurological manifestations and multisystemic involvement, first described by Jaeken et al. [1980]. The awareness that such a disorder may have a discrete clinical presentation should prompt a preliminary routine test based on isoelectric focusing of serum transferrins or on Western blot analysis of the serum glycoproteins [Seta et al., 1996].

Salomons et al. [2001] described a male child presenting at age 6 years with mild MR, severe speech delay, and hypotonia who was found to have increased levels of creatine in urine and plasma. Further investigations led to the identification of a new creatine deficiency syndrome.

It seems, therefore, worthwhile suggesting a careful consideration of a "general first-step" metabolic workup in all DD/MR children, in order to avoid

\section{It seems, therefore, worthwhile suggesting a careful consideration of a "general first-step" metabolic workup in all DD/MR children, in order to avoid missing some metabolic conditions with a discrete clinical presentation.}

missing some metabolic conditions with a discrete clinical presentation.

\section{NEUROIMAGING STUDIES}

An individual with MR has, by definition, a functionally abnormal brain, which does not necessarily match with anatomical abnormalities. Structural brain abnormalities have been described in 34-98\% of deceased severely retarded patients undergoing neuropathologic studies [Crome, 1960; Warkany, 1971; Polednak, 1974], whereas abnormalities on neuroimaging were reported in 9$60 \%$ of living patients [Moeschler et al., 1981; Lingam et al., 1982; Sugimoto et al., 1993; Majnemer and Shevell, 1995; Curry et al., 1996; Root and Carey, 1997; Hunter, 2000]. This wide range of results is probably related to the date and type of study (computed tomography (CT) vs. magnetic resonance imaging (MRI)), and to the patient selection criteria. According to the literature data, the Consensus Conference [Curry et al., 1997] stated that "neuroimaging appears to have an especially important role in patients with microcephaly or macrocephaly, seizures, loss of psychomotor skills and neurologic signs," while its value in the normocephalic patient with no focal neurological signs is unclear.

It is worth mentioning that recently two sisters, aged 4 and 6 years, respectively, were referred to the institute of one of the authors (A.B.) because of mild MR and severe language delay. Parents were unrelated. There were no focal neurological signs, and occipitofrontal circumference (OFC) and physical examination were normal. Standard cytogenetics, routine blood and urine analysis, and metabolic workup were normal. Nonetheless, both girls underwent conventional MRI and brain proton MRS. MRI was normal, whereas MRS disclosed the total absence of creatine/phosphocreatine peak in the periventricular white matter, the cerebellum, and the parieto-occipital cortex [Bianchi et al., 2000]. Consequent investigation of the creatine biosynthetic pathway led to the identification of a new inborn error of creatine metabolism [Item et al., 2001]. Creatine monohydrate oral administration resulted in almost complete brain creatine level restoration along with improvement of the patients' disabilities.

MRS of the brain showing an almost complete absence of the creatine signal again prompted further investigations leading to diagnosis in the patient reported by Salomons et al. [2001] (see above), whose OFC and neurological examination were normal.

In this light, it seems appropriate to perform state-of-the-art neuroimaging studies also in normocephalic DD/MR patients with no focal neurologic signs, in order to avoid missing the recognition of potentially "treatable" neurologic disorders [see Battaglia, 2003].

\section{It seems appropriate to perform state-of-the-art neuroimaging studies also in normocephalic DD/MR patients with no focal neurologic signs, in order to avoid missing the recognition of potentially "treatable" neurologic disorders.}

\section{EEG STUDIES}

Until a few years ago, very little, if anything, had been reported on the value of EEG studies in MR patients. Recently, Battaglia et al. [1999] reported a relatively high diagnostic yield of EEG investigations in DD/MR patients. They showed the usefulness of waking/ sleep video-EEG-polygraphic studies not only in the presence of a clinical history of seizures/epilepsy, but also in other specific clinical settings, such as significant language impairment, Angelman syndrome, inv dup(15) syndrome, and Wolf-Hirschhorn syndrome. In all these conditions, EEG can be helpful both for adequate treatment and for diagnostic purposes [Battaglia et al., 1996, 1997, 2001a, 2002; Guerrini 


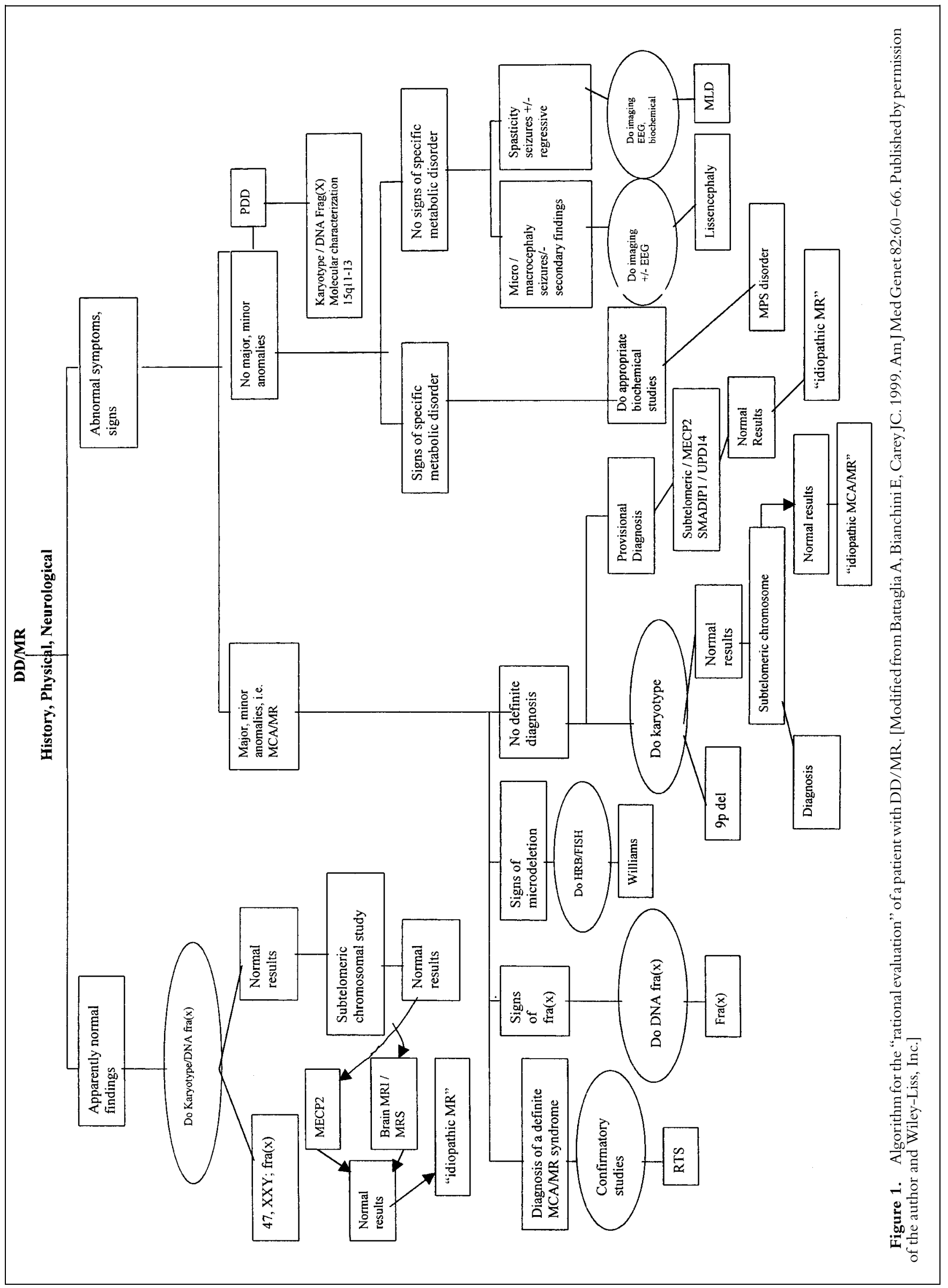


et al., 1996]. In addition, there are a few neurometabolic disorders in which EEG/evoked potentials show a typical pattern, highly suggestive of the diagnosis [Pampiglione and Harden, 1974; Harden and Pampiglione, 1982]. Still, particular EEG patterns observed in some genetic/chromosomal disorders may contribute to the understanding of the underlying pathophysiology [Kivitie-Kallio and Norio, 2001].

\section{CONCLUSIONS}

As already discussed [Battaglia et al., 1999], we would suggest that the practitioner follow an algorithm for the

\section{We would suggest that the practitioner follow an algorithm for the "rational evaluation" of a patient with DD/MR.}

"rational evaluation" of a patient with $\mathrm{DD} / \mathrm{MR}$, and given the latest scientific and technical advances, this should now be updated as from Figure 1. Based on historical and physical examination, the workup of a DD/MR patient can follow various pathways that guide decisions regarding the most appropriate laboratory testing and imaging studies.

As mentioned above, during recent few years there has been substantial progress in molecular cytogenetics and neuroimaging techniques, the use of which have allowed recognition and definition of new disorders, thus increasing the diagnostic yield.

Based on the latest knowledge, and in an attempt to carry out a rational evaluation with the highest possible yield, we would recommend subdividing $\mathrm{DD} / \mathrm{MR}$ patients with no definite diagnosis into the following categories:

1. Patients thought to be nonsyndromic-Do HRB + (if not microcephalic) DNA FraX analysis, and if normal, proceed to subtelomeric analysis; if normal, consider DNA analysis searching for MECP2 mutations/deletions, and brain MRS.

2. Patients with physical anomalies $+/$ - family history of MR, +/- prenatal and/or postnatal growth delay, overgrowth-Do $\mathrm{HRB}+$ (if not microcephalic) DNA FraX analysis, and if normal, do subtelomeric analysis.

3. Patients with autism spectrum disorder but no dysmorphic findings or just one to four minor anomalies +/- epilepsy-Do standard cytogenetics and complete cytogenetic/ molecular characterization of $15 \mathrm{q} 11$ 13 region.

4. Patients with hypotonia and a PraderWilli syndrome-like phenotypeDo DNA methylation studies; if normal, do DNA FraX analysis; if normal, do DNA analysis for UPD14, and research for MECP2 mutations [Kleefstra et al., 2002].

5. Patients with an Angelman syndrome-like phenotype-Do DNA methylation studies; if normal, do $\mathrm{HRB}$, and if normal, proceed to subtelomeric analysis (to exclude 22q13.3 aberrations), and consider comparative genomic hybridization (to exclude $2 \mathrm{q} 21-23$ or $4 \mathrm{q}$ or $17 \mathrm{q} 23.2$ aberrations); or if normal, do DNA analysis searching for MECP2 mutations/deletions; and if normal, do complete cytogenetic/molecular characterization of 15q11-13 region; and/or search for methylene tetrahydropholate reductase deficiency (MTHFR); and/or do mutation testing for the ATR-X gene; and/ or molecular analysis searching for mutations in the SMADIP1 gene.

6. Patients with distinct facial features $+/-$ microcephaly +/- HSCR/ constipation $+/-$ midline defectsDo HRB searching for 2 q22 aberrations, and if normal, do molecular analysis searching for mutations in the SMADIP1 gene.

7. Patients with either progressive or nonprogressive neurological symptoms-(Especially if males) do DNA analysis searching for MECP2 mutations/deletions, plasma/urine creatine levels, and (especially if cerebellar signs are present) iso- electric focusing of serum transferrins or Western blot analysis of the serum glycoproteins; and eventually appropriate metabolic workup (see below).

8. Patients with clinical and physical findings suggestive of metabolic disorders-Do the appropriate metabolic workup [see Kahler and Fahey, 2003].

Careful waking/sleep video-EEGpolygraphic studies should be taken into consideration at least in definite cases. Systematic follow-up of the patient should be carried out routinely. On many occasions this has been helpful for diagnosis.

Although it is obvious to us that no set protocol can replace the individual clinician's freedom to decide what test to carry out, we believe that the above recommendations might help toward a more rational and comprehensive assessment of the DD/MR patient.

\section{REFERENCES}

Achenbach TM. 1991. Manual for the child behavior checklist/4-18 and 1991 profile. Burlington, VT: University of Vermont, Department of Psychiatry.

Allen WP, Taylor H. 1996. Mental retardation in South Carolina VII. Inborn errors of metabolism. Proc Greenwood Genet Ctr 15:76-79.

American Psychiatric Association. 1995. Diagnostic and statistical manual of mental disorders (DSM-IV). Washington, DC: American Psychiatric Association. p 3946.

Amiel J, Espinosa-Parrilla Y, Steffan J, Gosset P, Pelet A, Prieur M, Boute O, Choiset A, Lacombe D, Philip N, Le Merrer M, Tanaka H, Till M, Touraine R, Toutain A, Vekemans M, Munnich A, Lyonnet S. 2001. Large-scale deletions and SMADIP1 truncating mutations in syndromic Hirschsprung disease with involvement of midline structures. Am J Hum Genet 69:13701377.

Amir RE, Van der Veyver IB, Wan M, Tran CQ, Francke U, Zoghbi HY. 1999. Rett syndrome is caused by mutations in $\mathrm{X}$ linked MECP2, encoding methyl$\mathrm{CpG}$ binding protein 2. Nat Genet 23: 185-188.

Anderlid BM, Schoumans J, Anneren G, Sahlen S, Kyllerman M, Vujic M, Hagberg B, Blennow E, Nordenskjold M. 2002. Subtelomeric rearrangements detected in patients with idiopathic mental retardation. Am J Med Genet 107:275-284.

Arn PH, Williams CA, Zori RT, Driscoll DJ, Rosenblatt DS. 1998. Methylenetetrahy- 
dropholate reductase deficiency in a patient with phenotypic findings of Angelman syndrome. Am J Med Genet 77: 198-200.

ASHG/ACMG Report. 1996. Diagnostic testing for Prader-Willi and Angelman syndrome: report of the ASHG/ACMG test and technology transfer committee. Am J Hum Genet 58:1085-1088.

Baker E, Hinton L, Callen DF, Altree M, Dobbie A, Eyre HJ, Sutherland GR, Thompson E, Thompson P, Woollatt E, Haan E. 2002. Study of 250 children with idiopathic mental retardation reveals nine cryptic and diverse subtelomeric chromosome anomalies. Am J Med Genet 107:285-293.

Battaglia A. 2003. Neuroimaging studies in the evaluation of developmental delay/mental retardation. Am J Med Genet (Semin Med Genet) 117C:25-30.

Battaglia A, Carey JC, Thompson JA, Filloux FM. 1996. EEG studies in the Wolf-Hirschhorn (4p-) syndrome. Electroencephalogr Clin Neurophysiol 99:324.

Battaglia A, Gurrieri F, Bertini E, Bellacosa A, Pomponi MG, Paravatou-Petsotas M Mazza S, Neri G. 1997. The inv dup(15) syndrome: a clinically recognizable syndrome with altered behavior, mental retardation, and epilepsy. Neurology 48:10811086.

Battaglia A, Bianchini E, Carey JC. 1999. Diagnostic yield of the comprehensive assessment of developmental delay/mental retardation in an institute of child neuropsychiatry. Am J Med Genet 82:60-66.

Battaglia A, Carey JC, Wright TJ. 2001a. WolfHirschhorn (4p-) syndrome. Adv Pediatr 48:75-113

Battaglia A, Viskochil DH, Lewin SO, Bamshad M, Chen Z, Lamb AN, Palumbos JP, Berkheim L, Carey JC. 2001b. 1p deletion syndrome: a common, important and often missed cause of developmental delay/mental retardation. Am J Hum Genet 69:193.

Battaglia A, Carey JC, Wright TJ. May 2002. Wolf-Hirschhorn syndrome. In: GeneReviews: genetic disease online reviews at GeneTests-GeneClinics [Database online]. Copyright, University of Washington, Seattle. Available at http://www.geneclinics. org.

Berends MJW, Hordijk R, Scheffer H, Oosterwijk JC, Halley DJJ, Sorgedrager N. 1999. Two cases of maternal uniparental disomy 14 with a phenotype overlapping with the Prader-Willi phenotype. Am J Med Genet 84:76-79

Bianchi MC, Tosetti M, Fornai F, Alessandri MG, Cipriani P, De Vito G, Canapicchi R. 2000. Reversible brain creatine deficiency in two sisters with normal blood creatine level. Ann Neurol 47:511-513.

Bienvenue T, Carrie A, de Roux N, Viner MC, Jonveau P, Couvert P, Villard L, Arzimanoglou A, Beldjord C, Fontes M, Tardieu M, Chelly J. 2000. MECP2 mutations account for most cases of typical forms of Rett syndrome. Hum Mol Genet 9:1377-1384.

Biesecker LG. 2002. The end of the beginning of chromosome ends. Am J Med Genet 107:263-266.

Blennow E, Nielsen KB, Telenius H, Carter NP, Kristoffersson U, Holmberg E, Gillberg C,
Nordenskjold M. 1995. Fifty probands with extra structurally abnormal chromosomes characterized by fluorescence in situ hybridization. Am J Med Genet 55:85-94.

Bodensteiner JB, Schaefer GB. 1995. Evaluation of the patient with idiopathic mental retardation. J Neuropsychiatry 7:361-370.

Bolton P, MacDonald H, Pickles A, Rios P, Goode S, Crowson M, Bailey A, Rutter M. 1994. A case-control family history study of autism. J Child Psychol Psychiatry 35:877900.

Bourgeois M, Benezech M. 1977. Cytogenetic survey of 600 mentally retarded hospitalized patients. Encephale 3:361-370.

Browne CR, Dennis NR, Maher E, Long FL, Nicholson JC, Sillibourne J, Barber JCK. 1997. Inherited interstitial duplications of proximal 15q: genotype-phenotype correlations. Am J Hum Genet 61:1342-1352.

Butler MG. 1995. High resolution chromosome analysis and fluorescence in situ hybridization in patients referred for Prader-Willi or Angelman syndrome. Am J Med Genet 56:420-422.

Cheadle SP, Gill H, Fleming N, Maynard J, Kerr A, Leonard H, Krawczak M, Cooper DN, Lynch S, Thomas N, Hughes H, Hulten M Ravine D, Sampson JR, Clarke A. 2000. Long-read sequence analysis of the MECP2 gene in Rett syndrome patients: correlation of disease severity with mutation type and location. Hum Mol Genet 9:11191129.

Cheng SD, Spinner NB, Zackai EH, Knoll JHM. 1994. Cytogenetic and molecular characterization of inverted duplicated chromosomes 15 from 11 patients. Am J Hum Genet 55:753-759.

Cook EH, Lindgren V, Leventhal BL, Courchesne R, Lincoln A, Shulman C, Lord C, Courchesne E. 1997. Autism or atypical autism in maternally but not paternally derived proximal $15 \mathrm{q}$ duplication. Am J Hum Genet 60:928-934.

Cora T, Demirel S, Acar A. 2000. Chromosomal abnormalities in mentally retarded children in the Konya region-Turkey. Genet Couns 11:53-55.

Cotter PD, Kaffe S, McCurdy LD, Jhaveri M, Willner JP, Hirschhorn K. 1997. Paternal uniparental disomy for chromosome 14: case report and review. Am J Med Genet 70:74-79.

Couvert P, Bienvenue T, Aquaviva C, Poirier K, Moraine C, Gendrot C, Verloes A, Andrès C, Le Fevre AC, Souville I, Steffan J, des Portes V, Ropers HH, Yntema HG, Fryns JP, Briault S, Chelly J, Cherif B. 2001. MECP2 is highly mutated in X-linked mental retardation. Hum Mol Genet 10:941-946.

Crome L. 1960. The brain and mental retardation. Br Med J 1:897.

Curry CJ, Sandhu A, Frutos L, Wells R. 1996. Diagnostic yield of genetic evaluations in developmental delay/mental retardation. Clin Res 44:130A.

Curry CJ, Stevenson RE, Aughton D, Byrne J, Carey JC, Cassidy S, Cunniff C, Graham JM Jr, Jones MC, Kaback MM, Moeschler J, Schaefer BG, Schwartz S, Tarleton J, Opitz J of the American College of Medical Genetics. 1997. Evaluation of mental retardation: recommendations of a consensus conference. Am J Med Genet 72:468-477.

De Bona C, Zappella M, Hayek G, Meloni I, Vitelli F, Bruttini M, Cusano R, Loffredo P, Longo I, Renieri A. 2000. Preserved speech variant is allelic of classic Rett syndrome. Eur J Hum Genet 8:325-330.

De Vries BBA, White SM, Knight SJL, Regan R, Homphray T, Young JD, Super M, McKeown C, Splitt M, Quarrell OWJ, Trainer AH, Niermeijer MF, Malcolm S, Flint J, Hurst JA, Winter RM. 2001. Clinical studies on submicroscopic subtelomeric rearrangements: a checklist. J Med Genet 38:145-150.

Delach JA, Rosengren SS, Kaplan L, Greenstein RM, Cassidy SB, Benn PA. 1994. Comparison of high resolution chromosome banding and fluorescence in situ hybridization (FISH) for the laboratory evaluation of Prader-Willi syndrome and Angelman syndrome. Am J Med Genet 52:85-91.

Drillien CM, Pickering RM, Drummond MB. 1988. Predictive value of screening for difficult areas of development. Dev Med Child Neurol 30:294-305

Drouin-Garraud V, Belgrand M, Grunewald S, Seta N, Dacher JN, Henocq A, Matthijs G, Cormier-Daire V, Frebourg T, SaugierVeber P. 2001. Neurological presentation of a congenital disorder of glycosylation CDG-1a: implications for diagnosis and genetic counseling. Am J Med Genet 101:46-49.

Ellaway C, Buchholz T, Smith A, Leonard H, Christodoulou J. 1998. Rett syndrome: significant clinical overlap with Angelman syndrome but not with methylation status. J Child Neurol 13:448-451.

Felix TM, Leite JC, Maluf SW, Coelho JC. 1998. A genetic diagnostic survey in a population of 202 mentally retarded institutionalized patients in the south of Brazil. Clin Genet 54:219-223.

Flejter WL, Bennet-Beker PE, Ghaziuddin M, McDonald M, Sheldon S, Gorski JL. 1996. Cytogenetic and molecular analysis of inv dup (15) chromosomes observed in two patients with autistic disorder and mental retardation. Am J Med Genet 11: 182-187.

Gibbons RJ, Brueton L, Buckle VJ, Burn J, Clayton-Smith J, Davison BC, Garner RJ, Homfray T, Kearney L, Kingston HL, Newbury-Ecob R, Porteous MEP, Wilkie AOM, Higgs DR. 1995. Clinical and hematologic aspects of the X-linked $\alpha$ thalassemia/mental retardation syndrome (ATR-X). Am J Med Genet 55:288-299.

Giraudeau F, Aubert D, Young J, Horsley S, Knight S, Kearney L, Vergnaud G, Flint J. 1997. Molecular cytogenetic detection of a deletion of $1 \mathrm{p} 36.3$ leads to a revised estimate of the frequency of subtelomeric rearrangements in idiopathic mental retardation. J Med Genet 34:314-317.

Giraudeau F, Taine L, Biancalana V, Delobel B, Journel $\mathrm{H}$, Missirian C, Lacombe D, Bonneau D, Parent P, Aubert D, Hauck Y, Croquettes MF, Toutain A, Mattei MG, Loiseau HA, David A, Vergnaud G. 2001. Use of a set of highly polymorphic minisatellite probes for the identification of cryptic 1 p36.3 deletions in a large collection 
of patients with idiopathic mental retardation. J Med Genet 38:121-125.

Guerrini R, De Lorey TM, Bonanni P, Moncla A, Dravet C, Suisse G, Livet MO, Bureau M, Malzac P, Genton P, Thomas P, Sartucci P, Simi P, Serratosa JM. 1996. Cortical myoclonus in Angelman syndrome. Ann Neurol 40:39-48.

Guerrini R, Shanahan JL, Carrozzo R, Bonanni P, Higgs DR, Gibbons RJ. 2000. A nonsense mutation of the ATR-X gene causing mild mental retardation and epilepsy. Ann Neurol 47:117-121.

Gurrieri F, Battaglia A, Torrisi L, Tancredi R, Cavallaro C, Sangiorgi E, Neri G. 1999. Pervasive developmental disorder and epilepsy due to maternally derived duplication of 15q11-q13. Neurology 52:1694-1697.

Gustavson KH, Hagberg B, Hagberg G, Sars K. 1977a. Severe mental retardation in a Swedish county: I. epidemiology, gestational age, birth weight and associated CNS handicap in children born 1959-70. Acta Paediatr Scand 66:373-379.

Gustavson KH, Hagberg B, Hagberg G, Sars K. 1977b. Severe mental retardation in a Swedish county: II. etiologic and pathogenetic aspects of children born 1959-1970. Neuropaediatrie 8:293-304.

Harden A, Pampiglione G. 1982. Neurophysiological studies (EEG/ERG/VEP/SEP) in 88 children with so-called neuronal ceroid lipofuscinosis. In: Armstrong D, Koppang N, Rider JA, editors. Ceroid lipofuscinosis (Batten's disease). Amsterdam: Elsevier Biomedical Press. Chap. 4.

Holinski-Feder E, Reyniers E, Uhrig S, Golla A, Wauters J, Kroisel P, Bossuyt P, Rost I, Jedele K, Zierler A, Schwab S, Wieldenauer D, Speicher MR, Willems PJ, Meitinger T, Kooy RF. 2000. Familial mental retardation syndrome ATR-16 due to an inherited cryptic subtelomeric translocation, $\mathrm{t}(3 ; 16)(\mathrm{q} 29 ; \mathrm{p} 13.3)$. Am J Hum Genet 66:16-25.

Hong KE, Kim JH, Moon SY, Oh SK. 1999. Chromosomal abnormalities in child psychiatric patients. J Korean Med Sci 14:377385.

Hordijk R, Wierenga H, Scheffer H, Leegte B, Hofstra RMW, Stolte-Dijkstra I. 1999. Maternal uniparental disomy for chromosome 14 in a boy with a normal karyotype. J Med Genet 36:782-785

Hou JW, Wang TR, Chuang SM. 1998. An epidemiological and aetiological study of children with intellectual disability in Taiwan. J Intellect Disabil Res 42:137-143.

Hunter AGW. 2000. Outcome of the routine assessment of patients with mental retardation in a genetics clinic. Am J Med Genet 90:60-68.

Huppke P, Laccone F, Kramer N, Engel W, Hanefeld F. 2000. Rett syndrome: analysis of MECP2 and clinical characterization of 31 patients. Hum Mol Genet 9:1369-1375.

Imessaoudene B, Bonnefont JP, Royer G, Cormier-Daire V, Lyonnet S, Lyon G, Munnich A, Amiel J. 2001. MECP2 mutation in nonfatal, non-progressive encephalopathy in a male. J Med Genet 38:171-174.

Item CB, Stockler-Ipsiroglu S, Stromberger C, Muhl A, Alessandri MG, Bianchi MC, Tosetti M, Fornai F, Cioni G. 2001.
Arginine: glycine amidinotransferase deficiency: the third inborn error of creatine metabolism in humans. Am J Hum Genet 69:1127-1133.

Jaeken J, Vanderschueren-Lodeweyckx M, Casaer P, Snoeck L, Corbeel L, Eggermont E, Eeckels R. 1980. Familial psychomotor retardation with markedly fluctuating serum proteins, FSH and GH levels, partial TBG deficiency, increased serum arylsulphatase A and increased CSF protein: a new syndrome? Pediatr Res 14:179.

Jorde LB, Mason-Brothers A, Waldmann R, Ritvo ER, Freeman BJ, Pingree C, McMahon WM, Petersen B, Jenson WR, Mo A. 1990. The UCLA-University of Utah epidemiologic survey of autism: genealogical analysis of familial aggregation. Am J Med Genet 36:85-88.

Kahler SG, Fahey MC. 2003. Metabolic disorders and mental retardation. Am J Med Genet (Semin Med Genet) 117C:31-41.

Kim SJ, Cook EHJ. 2000. Novel de novo nonsense mutation of MECP2 in a patient with Rett syndrome. Hum Mutat 15:382382.

Kivitie-Kallio S, Norio R. 2001. Cohen syndrome: essential features, natural history, and heterogeneity. Am J Med Genet 102:125135.

Kleefstra T, Yntema HG, Oudakker AR, Romein $\mathrm{T}$, Sistermans E, Nillessen W, van Bokhoven $\mathrm{H}$, de Vries BBA, Hamel BLT. 2002. De novo MECP2 frameshift mutation in a boy with moderate mental retardation, obesity and gynaecomastia. Clin Genet 61:359362 .

Knight SJL, Flint J. 2000. Perfect endings: a review of subtelomeric probes and their use in clinical diagnosis. J Med Genet 37:401409.

Knight SJL, Horsley SW, Regan R. 1997. Development and clinical application of an innovative fluorescence in situ hybridization technique which detects submicroscopic rearrangements involving telomeres. Eur J Hum Genet 5:1-8.

Knight SJL, Regan R, Nicod A, Horsley SW, Kearney L, Homfray T, Winter RM, Bolton P, Flint J. 1999. Subtle chromosomal rearrangements in children with unexplained mental retardation. Lancet 354:16761681.

Kodama Y. 1982. Cytogenetic and dermatoglyphic studies on severely handicapped patients in an institution. Acta Med Okayama 36:383-397.

Kuwano A, Mutirangura A, Dittrich B, Buiting K, Horstemke B, Saitoh S, Niikawa N, Ledbetter SA, Greenberg F, Chinault AC, Ledbetter DH. 1992. Molecular dissection of the Prader-Willi/Angelman syndrome region (15q11-13) by YAC cloning and FISH analysis. Hum Mol Genet 1:417-425.

Laxova R, Ridler MAC, Bowen-Bravery M. 1977. An etiological survey of the severely retarded Hertfordshire children who were born between January 1, 1965 and December 31, 1967. Am J Med Genet 1:75-86.

Lee KA, Kim SH, Lee MH, Law ME, Jalal SM. 2001. Tandem translocation of chromosomes 22 and 15 with two preserved satellite stalk regions and deletion 22q13.3-qter. Am J Med Genet 104:291-294.
Lehrke RG. 1968. Sex-linked mental retardation and verbal disability. $\mathrm{PhD}$ dissertation, University of Wisconsin, Madison, WI. Ann Arbor, MI: University Microfilms.

Lindor NM, Valdes MG, Wick M, Thibodeau SN, Jalal S. 1997. De novo 16p deletion: ATR-16 syndrome. Am J Med Genet 72:451-454

Lingam S, Read S, Holland IM, Wilson J, Brett EM, Hoare RD. 1982. Value of computerised tomography in children with nonspecific mental subnormality. Arch Dis Child 57:381-383.

Lurie IW, Supovitz KR, Rosenblum-Vos LS, Wulfsberg EA. 1994. Phenotypic variability of $\operatorname{del}(2)$ (q22-q23): report of a case with a review of the literature. Genet Couns 5: $11-14$

Majnemer A, Shevell MI. 1995. Diagnostic yield of the neurologic assessment of the developmentally delayed child. J Pediatr 127: 193-199.

Maraschio P, Cuoco C, Gimelli G, Zuffardi O, Tiepolo L. 1988. Origin and clinical significance of inv dup (15). In: Danil A, editor. The cytogenetics of mammalian autosomal rearrangements. New York: Alan R. Liss. p 615-634.

Martin RA, Sabol DW, Rogan PK. 1999. Maternal uniparental disomy of chromosome 14 confined to an interstitial segment (14q23-14q24.2). J Med Genet 36:633636.

Massey PS, McDermott S. 1995. State-specific rates of mental retardation-United States, 1993. MMWR 45:61-65.

McLaren J, Bryson SE. 1987. Review of recent epidemiological studies of mental retardation: prevalence, associated disorders, and etiology. Am J Mental Retard 92:243-254.

Meloni I, Bruttini M, Longo I, Mari F, Rizzolio F, D'Adamo P, Denvriendt K, Fryns JP, Toniolo D, Renieri A. 2000. A mutation in the Rett syndrome gene, MECP2, causes $\mathrm{X}$-linked mental retardation and progressive spasticity in males. Am J Hum Genet 67:982-985

Moeschler JB, Bennet FC, Cromwell LD. 1981. Use of the CT scan in the medical evaluation of the mentally retarded child. J Pediatr 98:63-65.

Mohandas TK, Park JP, Spellman RA, Filiano JJ, Mamourian AC, Hawk AB, Belloni DR, Noll WW, Moeschler JB. 1999. Paternally derived de novo interstitial duplication of proximal $15 \mathrm{q}$ in a patient with developmental delay. Am J Med Genet 82:294-300.

Moser HW, Wolf PA. 1971. The nosology of mental retardation: including the report of a survey of 1378 mentally retarded individuals at the Walter E. Fernald State School. Birth Defects Orig Artic Ser 7(1):117-134.

Moser HW, Ramey CT, Leonard CO. 1990. Mental retardation. In: Emery AEH, Rimoin DL, editors. Principles and practice of medical genetics, 2nd edition. Edinburgh: Churchill Livingstone. p 495-511.

Mowat DR, Croaker GDH, Cass DT, Kerr BA, Chaitow J, Adès LC, Chia NL, Wilson MJ. 1998. Hirschsprung disease, microcephaly, mental retardation, and characteristic facial features: delineation of a new syndrome and identification of a locus at chromosome 2q22-q23. J Med Genet 35:617-623. 
Nanni L, Ming JE, Du Y, Hall RK, Aldred M, Bankier A, Muenke M. 2001. SHH mutation is associated with solitary median maxillary central incisor: a study of 13 patients and review of the literature. Am J Med Genet 102:1-10.

Opitz JM, Kaveggia EG, Durkin-Stamm MV, Pendleton E. 1978. Diagnostic/genetic studies in severe mental retardation. Birth Defects Orig Artic Ser 15(6B):1-38.

Opitz JM, Kaveggia EG, Laxova R, Pallister PD. 1982. The diagnosis and prevention of severe mental retardation, volume II. In: Proceedings, International Conference on Preventable Aspects of Genetic Morbidity, Cairo. p 117-138.

Orrico A, Lam CW, Galli L, Dotti MT, Hayek G, Tong SF, Poon PMK, Zappella M, Federico A, Sorrentino V. 2000. MECP2 mutation in male patients with non-specific X-linked mental retardation. FEBS Lett 481:285288.

Pampiglione G, Harden A. 1974. An infantile form of neuronal storage disease with characteristic evolution of neurophysiological features. Brain 97:355-360.

Papenhausen PR, Mueller OT, Johnson VP, Sutcliffe M, Diamond TM, Koussef BG. 1995. Uniparental isodisomy of chromosome 14 in two cases: an abnormal child and a normal adult. Am J Med Genet 59:271275

Penrose LS. 1938. A clinical and genetic study of 1280 cases of mental defect. Special Report Series, Medical Research Council, No. 229. London: Her Majesty's Stationery Office.

Phelan MC, Crawford EC, Bealer DM. 1996. Mental retardation in South Carolina III: chromosome aberrations. Proc Greenwood Genet Ctr 15:45-60.

Phelan MC, Rogers RC, Saul RA, Stapleton GA, Sweet K, McDermid H, Shaw SR, Claytor J, Willis J, Kelly DP. 2001. 22q13 deletion syndrome. Am J Med Genet 101:91-99.

Piven J, Gayle J, Chase GA, Fink B, Landa R, Wzorek MM, Folstein SE. 1990. A family history study of neuropsychiatric disorders in the adult siblings of autistic individuals. J Am Acad Child Adolesc Psychiatry 29:177183.

Polednak AP. 1974. Postmortem neuropathology in a mentally retarded population. Lancet 26:1126-1128.

Precht KS, Lese CM, Spiro RP, Huttenlocker PR, Johnston KM, Baker JC, Christian SL, Kittikamron K, Ledbetter DH. 1998. Two 22q telomere deletions serendipitously detected by FISH. J Med Genet 35:939942.

Rasmussen K, Nielsen J, Dahl G. 1982. The prevalence of chromosome abnormalities among mentally retarded persons in a geographically delimited area of Denmark. Clin Genet 22:244-255.

Riegel M, Castellan C, Balmer D, Brecevic L, Schinzel A. 1999. Terminal deletion, del(1)(p36.3), detected through screening for terminal deletions in patients with unclassified malformation syndromes. Am J Med Genet 82:249-253.

Riordan D, Dawson AJ. 1998. The evaluation of 15q proximal duplications by FISH. Clin Genet 54:517-521.
Robinson WP, Binkert F, Gine R, Vazquez C, Muller W, Rosenkranz W, Schinzel A. 1993. Clinical and molecular analysis of five inv dup (15) patients. Eur J Hum Genet 1: $37-50$.

Root S, Carey JC. 1997. Brain dysmorphology and developmental disabilities. Proc Greenwood Genet Ctr 16:224.

Rossi E, Piccini F, Zollino M, Neri G, Caselli D, Tenconi R, Castellan C, Carrozzo R, Danesino C, Zuffardi O, Ragusa A, Castiglia L, Galesi O, Greco D, Romano C, Pierluigi M, Perfumo C, Di Rocco M, Faravelli F, Dagna Bricarelli F, Bonaglia MC, Bedeschi MF, Borgatti R. 2001. Cryptic telomeric rearrangements in subjects with mental retardation associated with dysmorphism and congenital malformations. J Med Genet 38:417-420.

Saccone S, De Sario A, Della Valle G, Bernardi G. 1992. The highest gene concentrations in the humane genome are in telomeric bands of metaphase chromosomes. Proc Natl Acad Sci USA 89:4913-4917.

Salomons GS, van Dooren SJM, Verhoeven NM, Cecil KM, Ball WS, Degraw TJ, Jakobs C. 2001. X-linked creatine-transporter gene (SLC6A8) defect: a new creatine-deficiency syndrome. Am J Hum Genet 68:14971500.

Schroer RJ, Phelan MC, Michaelis RC, Crawford EC, Skinner SA, Cuccaro M, Simensen RJ, Bishop J, Skinner C, Fender D, Stevenson RE. 1998. Autism and maternally derived aberrations of chromosome 15q. Am J Med Genet 76:327-336.

Seta N, Barnier A, Hochedez F, Besnard AM, Durand G. 1996. Diagnostic value of Western blotting in carbohydrate-deficient glycoprotein syndrome. Clin Chim Acta 24:131-140.

Simeonsson RJ, Sharp MC. 1992. Developmental delays. In: Hockelman RA, Friedman SB, Nelson NM, Seidel HM, editors. Primary pediatric care, 2nd ed. St. Louis: MosbyYear Book. p 867-870.

Slavotinek A, Shaffer LG, Shapira SK. 1999. Monosomy 1p36. J Med Genet 36:657663.

Sparrow SS, Balla DA, Cicchetti DV. 1984. Vineland adaptive behavior scales. Circle Pines, MN: American Guidance Service.

Srsen S, Misovicova N, Srsnova K, Volnà J. 1989. Chromosomal aberrations in a group of mentally retarded persons. Cesk Psychiatr 85:9-18.

Stevenson R. 1996. Mental retardation. Overview and historical perspective. Proc Greenwood Genet Ctr 15:19-25

Sugimoto T, Yasuhara A, Nishida N, Murakami K, Woo M, Kobayasashi Y. 1993. MRI of head in the evaluation of microcephaly. Neuropediatrics 24:4-7.

Szatmari P, Jones MB, Tuff L, Bartolucci G, Fisman S, Mahoney W. 1993. Lack of cognitive impairment in first-degree relatives of children with pervasive developmental disorders. J Am Acad Child Adolesc Psychiatry 32:1264-1273.

Thomas JA, Johnson J, Peterson Kraai TL, Wilson R, Tartaglia N, LeRoux J, Beischel L, McGavran L, Hagerman RJ. 2003. Genetic and clinical characterization of patients with an interstitial duplication 15q11-q13, emphasizing behavioral phenotype and response to treatment. Am J Med Genet (in press).

Van Karnebeek CDM, Koevoets C, Sluijter S, Bijlsma EK, Smeets DFMC, Redeker EJ, Hennekam RCM, Hoovers JMN. 2002. Prospective screening for subtelomeric rearrangements in children with mental retardation of unknown aetiology: the Amsterdam experience. J Med Genet 39: 546-553.

Villard L, Bonino MC, Abidi F, Ragusa A, Belougne J, Lossi AM, Seaver L, Bonnefont JP, Romano C, Fichera M, Lacombe D, Hanauer A, Philip N, Schwartz C, Fontes M. 1999. Evaluation of a mutation screening strategy for sporadic cases of ATR-X syndrome. J Med Genet 36:183-186.

Villard L, Kpebe ACC, Chelly J, Tardieu M, Fontes M. 2000. Two affected boys in a Rett syndrome family: clinical and molecular findings. Neurology 55:1188-1193.

Wakamatsu N, Yamada Y, Yamada K, Ono T, Nomura N, Taniguchi H, Kitoh H, Yamanaka T, Mushiake K, Kato K, Sonta S, Nagaya M. 2001. Mutations in SIP1, encoding Smad-interacting protein 1, cause a form of Hirschsprung disease. Nat Genet 27:369-370.

Walter CA, Shaffer LG, Kaye CL, Huff RW, Ghidoni PD, McCaskill C, McFarland MB, Moore CM. 1996. Short-limb dwarfism and hypertrophic cardiomyopathy in a patient with paternal isodisomy 14: 45,XY,Idic (14) (p11). Am J Med Genet 65:259-265.

Warkany J. 1971. Congenital malformations. Chicago: Year Book Medical Publishers.

Watson P, Black G, Ramsden S, Barrow M, Super M, Kerr B, Clayton-Smith J. 2001. Angelman syndrome phenotype associated with mutations in MECP2, a gene encoding a methyl CpG binding protein. J Med Genet 38:224-228.

Williams CA, Lossie A, Driscoll D, Philips Unit RC. 2001. Angelman syndrome: mimicking conditions and phenotypes. Am J Med Genet 101:59-64.

Wuu KD, Wuu SW, Liu IW. 1984. A cytogenetic survey of mentally retarded children in Taiwan: final report on the incidence of chromosome abnormalities. Proceedings of the National Science Council, Republic of China-Part B. Life Sci 8:83-88.

Wuu KD, Chiu PC, Li SY, Chen JY, Chao MC, Ko KJ, Wang TR, Hsiao KJ. 1991. Chromosomal and biochemical screening on mentally retarded school children in Taiwan. Jpn J Hum Genet 36:267-274.

Xiang F, Buervenich S, Nicolao P, Bailey ME, Zhang Z, Anvret M. 2000. Mutation screening in Rett syndrome patients. J Med Genet 37:250-255.

$\mathrm{Xu} \mathrm{J}$, Chen Z. 2003. Advances in molecular cytogenetics for the evaluation of mental retardation. Am J Med Genet (Semin Med Genet) 117C:15-24.

Yamada K, Yamada Y, Nomura N, Miura K, Wakako R, Haykawa C, Matsumoto A, Kumagai T, Yoshimura I, Miyazaki S, Kato K, Sonta S, Ono H, Yamanaka T, Nagaya M, Wakamatsu N. 2001. Nonsense and frameshift mutations in ZFHX1B, encoding Smad-interacting protein 1 , cause a complex developmental disorder with a great variety 
of clinical features. Am J Hum Genet 69:1178-1185.

Yntema HG, Oudakker AR, Kleefstra T, Hamel BCJ, van Bokhoven H, Chelly J, Kalscheuer VM, Fryns JP, Raynaud M, Moizard MP, Moraine C. 2002. In-frame deletion in MECP2 causes mild nonspecific mental retardation. Am J Med Genet 107: $81-83$.

Zweier C, Albrecht B, Mitulla B, Behrens R, Beese M, Gillessen-Kaesbach G, Rott HD, Rauch A. 2002. "Mowat-Wilson" syndrome with and without Hirschsprung disease is a distinct, recognizable multiple congenital anomalies-mental retardation syndrome caused by mutations in the zinc finger homeo box 1B gene. Am J Med Genet 108:177-181. 